\title{
Contradictions in Judicial Support for Capital Punishment in India and Bangladesh: Utilitarian Rationales
}

\author{
Carolyn Hoyle $^{1}$ (D) Saul Lehrfreund ${ }^{2,3}$
}

Received: 8 July 2019/Revised: 4 October 2019/Accepted: 6 November 2019/Published online: 26 November 2019 (C) The Author(s) 2019

\begin{abstract}
India and Bangladesh share a common history, and each has developed somewhat similarly since partition. However, while both countries now have relatively low murder rates, India has seen a decline in the rate of executions, while Bangladesh continues to impose death sentences and carry out executions at a higher rate. There have been challenges to the death penalty in India, restricting its use to exceptional cases. The same has not occurred in Bangladesh. Yet in both countries, systemic flaws in the criminal process are evident. This article draws on two original empirical research projects that explored judges' opinions on the retention and administration of capital punishment in India and Bangladesh. The data expose justice systems marred by corruption, incompetence, abuses of due process, and arbitrary and inconsistent treatment of defendants from arrest through to conviction and sentencing. It shows that those with the power to sentence to death have little faith in the integrity of the criminal process. Yet, a startling paradox emerges from these studies; despite personal knowledge of its flaws, judges have trust in the death penalty to deter crime and to realise other sentencing aims and feel retention benefits society. This is explained by reference to utilitarian values. Not only did our judges express strongly utilitarian justifications for sentencing people to death, in terms of their erroneous belief in its deterrent effect, but some also articulated utilitarian justifications for misconduct in pre-trial processes, suggesting that it was necessary to break the rules to secure convictions when the system was dysfunctional and ineffective.
\end{abstract}

Keywords India $\cdot$ Bangladesh $\cdot$ Elite opinion $\cdot$ Judges $\cdot$ Death penalty

Carolyn Hoyle

Carolyn.Hoyle@crim.ox.ac.uk

Saul Lehrfreund

Saul.Lehrfreund@smab.co.uk

1 Centre for Criminology, University of Oxford, St Cross Building, St Cross Street, Oxford OX1 3UL, UK

2 Death Penalty Project, London, UK

3 School of Law, University of Reading, London, UK 


\section{The Death Penalty in India and Bangladesh}

The neighbouring countries of India and Bangladesh developed somewhat similarly following partition, experiencing increasing rates of literacy and economic growth, improving political stability, and decreasing rates of crime and conflict, particularly since the 1970s. However, while India's declining murder rate since the early 1990s has coincided with a falling rate of executions, Bangladesh continues to impose death sentences and carry out executions at a higher rate than its neighbour, though it too has a relatively low murder rate. ${ }^{1}$

\section{India}

India has vastly decreased its use of the death penalty since the early years of independence when between 1953 and 1963, there were at least 1422 executions. Hence, though India has the largest population of South Asia (approximately 1.3 billion persons), it has only sporadic executions, typically several years apart. Although 162 death sentences were imposed in India in 2018, there have been only three executions over the past decade, leaving 426 prisoners on death row at the end of 2018 (Project 39a 2018).

Serious challenges to the retention and the administration of the death penalty in India have restricted its use to exceptional cases. In Bachan Singh v State of Punjab (1980), the Supreme Court of India upheld the constitutionality of the death penalty, but the judgment emphasized that: ${ }^{2}$

The extreme penalty can be inflicted only in gravest cases of extreme culpability. ... life imprisonment is the rule and the death sentence an exception ... [The death penalty should not be imposed] save in the rarest of rare cases when the alternative option is unquestionably foreclosed. [our emphasis]

Subsequently, the Court has continued to uphold the constitutionality of the death penalty as applied on the 'rarest of rare cases' principle, which imbues into court proceedings a strong presumption in favour of life recognising that the ultimate penalty of death must be reserved for exceptional cases (see Middleton et al. 2018). Since this is not further defined and no clear guidelines have been developed, individual judges must determine whether to impose a death sentence. $^{3}$ That said, legal scholars are clear that the 'rarest of rare' doctrine is not supposed to suggest the rarity of the offence as the qualifying factor; judges are meant to first identify and then balance aggravating factors (relating to the crime) with mitigating factors (related to the circumstances of the accused). Furthermore, judges are expected to give a liberal and expansive interpretation of mitigating factors, not least that the accused is beyond reformation. ${ }^{4}$

By such methods, the death penalty should only be applied when the option of life imprisonment is unquestionably foreclosed. Although evolving case law suggests that the rarest of rare doctrine is applied erratically (Lehrfreund and Hood 2016: 140), it is likely to have contributed to the declining number of death sentences imposed. The more recent

\footnotetext{
${ }^{1}$ In 1992, India's murder rate was 4.6 per 100,000 of the population; in 2016, it was almost half that, at 2.4: National Crime Records Bureau (2017), p. xviii. Bangladesh's murder rate is 2.2 per 100,000 (population of 165 million): https://data.worldbank.org/indicator/VC.IHR.PSRC.P5?locations=BD

${ }^{2}$ Bachan Singh v State of Punjab [1980] 2 SCJ 474 at 522, 524. See also full judgment, including dissent by Bhagwati J, who found the death penalty to be unconstitutional, Bachan Singh v State of Punjab [1983] 1 SCR (Supreme Court Review) 145 at 250, 252, 256.

${ }^{3}$ Machhi Singh v State of Punjab [1983] 3 SCC 470, AIR 1983 SC 957.

${ }^{4}$ Mithu v State of Punjab [1983] 2 SCC 277.
} 
abolition of the mandatory death penalty for certain narcotic possession crimes ${ }^{5}$ and illegal firearm use causing death ${ }^{6}$ in 2011 and 2012 respectively has also been a factor.

Authoritative reports have shone a light on death penalty practices. The 2015 Report by the Law Commission of India demonstrated that the death penalty does not serve the penological goal of deterrence any more than a life sentence would; that it diverts attention and resources from the ailing criminal justice system; that the death penalty is applied arbitrarily and typically in contravention of the guidelines as laid down in the Bachan Singh judgment; that there is no principled method for removing such arbitrariness from death sentencing even in a discretionary system (see also, Lehrfreund and Hood 2016); and that the penalty is imposed following pre-trial and trial processes that are deeply flawed and unfair (Law Commission of India 2015:216). A report by the National Law University of Delhi (2016) similarly showed that the death penalty is disproportionality imposed on the most vulnerable and marginalised people and that pre-trial and trial processes failed to provide due process of law.

Notwithstanding, recent years have seen some expansion in the scope of the death penalty, with the 2016 Anti-Hijacking Act providing the death penalty for hijacking resulting in death, and amendments to the Prevention of Child Sex Offences Act in 2018 allowing for the death penalty for raping a child under 12 , even if it does not result in death.

\section{Bangladesh}

There are roughly four times as many people detained under sentence of death in Bangladesh as in India. Bangladesh imposes the death penalty for a wide range of offences (FIDH 2010), although the majority of those sentenced to death have been convicted of murder. Between 1976 and 2017, Bangladesh executed 448 persons. $^{7}$ In 2017, there were six recorded executions (Amnesty International 2018) though none in 2018 (Amnesty International 2019). However, at least 229 persons were sentenced to death in 2018, more than double the rate of India.

There have been no constitutional challenges to the death penalty per se in Bangladesh, and the judiciary would appear to have resisted efforts at restriction. In 1978, an Amendment to s. 367(5) of the Criminal Procedure Code left the issue of sentencing in death penalty cases entirely to the discretion of the court (Rahman 2017: 205). Subsequent case law clarified that the death penalty was no longer the presumptive penalty for murder, ${ }^{8}$ and in the early $2000 \mathrm{~s}$, the rarest of rare doctrine was endorsed by the Supreme Court, ${ }^{9}$ favouring a far more restrictive approach to the imposition of the death penalty than the legislative guideline set by the amendment of 1978 .

However, the judiciary has not consistently applied the rarest of rare doctrine, and in the case of Ataur Mridha @ Ataur vs. State, ${ }^{10}$ the Appellate Division held that 'a sentence of death awarded to an offender under section 302 of the Penal Code is the rule and life imprisonment is

\footnotetext{
${ }^{5}$ Indian Harm Reduction Network $v$ Union of India 2012 Bom CR (Cri) 121 (Bombay High Court); see also Lehrfreund (2013: 41).

${ }^{6}$ State of Punjab v Dalbir Singh AIR 2012 SC 1040 (Supreme Court of India).

7 The Daily Manabzamin, 28 December 2017.

${ }^{8}$ Abed Ali $v$ The State 42 DLR (AD) (1990) 171.

${ }^{9}$ State vs. ASI Md. Ayub Ali Sardar and another, 23 BLD (HCD) (2003) 181; State Deviz and others vs. State, 9 MLR (HC) (2004) 344; State vs. Abdul Karim alias Gonesh \& others, 8 BLC (2003) 264; State vs. Mir Hossain alias Mira and others, 56 DLR (2004) 124.

${ }^{10}$ Criminal Appeal No. 15-16/2010, at: www.supremecourt.gov.bd/resources/documents/1047802_CA15 of2010.pdf (accessed January 2018).
} 
an exception' (Rahman 2017: 206). This was later cited with approval by the High Court in State vs. Oyshee Rahman. ${ }^{11}$ Hence, contrary to the approach to capital sentencing in India, where there is a strong presumption in favour of life, the courts in Bangladesh have endorsed an approach with a presumption in favour of death, unless there are extenuating circumstances. The abolition of the mandatory death penalty for a form of aggravated murder in $2015^{12}$, which affirmed the dominant Commonwealth view that the death penalty ought to be the exception rather than the norm, seems to have done little to reduce death sentences.

Bangladesh has also attracted critical attention for failures to protect the procedural rights of those exposed to the death penalty, with evidence that juveniles have been sentenced to death in recent years, that court proceedings do not meet international fair trial standards, and that on occasion defendants are sentenced to death in absentia and in special or military courts without due process (Amnesty International 2018, 2019). Rahman describes a 'rampant culture of impunity', 'lawlessness', inequality, systematic abuses of the coercive authority of the state, and arbitrary and inconsistent sentencing (Rahman 2017: 228). Notwithstanding evidence of arbitrary injustice, the public appears to be supportive of capital punishment (Khondaker et al. 2011: 123-40).

\section{Opinions on the Death Penalty}

Where abolition has come about, it has not been as a result of the majority of the public demanding it. Indeed, in most cases, it has been driven by political elites in spite of overwhelming support by the public. Yet, when faced with critics of capital punishment, retentionist governments typically fall back on the argument that the public are not ready for abolition and that political leaders should represent 'the will of the people' (Hood and Hoyle 2017). However, measuring the will of the people is far from straightforward.

In the landmark case, Furman v Georgia, which imposed temporary abolition of the death penalty in the USA in 1973, former Justice of the U.S. Supreme Court Thurgood Marshall conjectured that people are supportive of capital punishment because they are not well informed about it. He opined that, given sound information, 'the great mass of citizens would conclude ... that the death penalty is immoral and therefore unconstitutional', and public opinion would shift towards the abolitionist position (Bohm 2003: 35). When tested by empirical research, several studies have found evidence to support the 'Marshall hypothesis' (Mitchell 2006; Cochran and Cochran 2011), but other research has not (Bohm and Vogel 1994; Sato 2014).

Hood's comparative analysis of public opinion research from eight countries ${ }^{13}$ indicates that support for capital punishment is largely dependent on assumptions and misconceptions about the administration of the death penalty. Most survey respondents admitted that they knew little about the administration of the death penalty and had little interest in it; only a few were well informed (Hood 2018:226). Evidence of significant failures of due process safeguards to protect the vulnerable, and the innocent have been shown to influence public opinion in countries such as Japan (Sato 2014), USA (Baumgartner et al. 2008: 101), and Singapore (Cheong et al. 2018).

\footnotetext{
${ }^{11}$ Death Reference No.99 of 2015, at: www.supremecourt.gov.bd/resources/documents/1034142_ DeathReference99of2015pdf.pdf (accessed January 2018).

${ }^{12}$ Bangladesh Legal Aid and Services Trust (BLAST) v Bangladesh 1 SCOB [2015] AD 1 (Bangladesh Supreme Court, Appellate Division).

${ }^{13}$ China, Trinidad, Malaysia, Singapore, Taiwan, Ghana, Japan, and Belarus.
} 
When respondents in China, Trinidad, Taiwan, and Malaysia were asked whether they would still favour the death penalty if it were proven to their satisfaction that an innocent person had been executed, support for the death penalty declined significantly (Hood 2018).

These studies demonstrate that support for the death penalty rests on a belief that the system will and can be administered without error and tends to dwindle when faith in the system diminishes. However, to date, no one has sought to establish if such knowledge has an impact on the opinions of those who are, or who have been, responsible for the administration of justice. We set out to explore knowledge about flaws in the criminal process and its influence on opinions about the death penalty among legal elites-judges who have worked within a capital punishment system.

\section{Methodological Reflections}

This article draws on two elite opinion surveys with former judges in India and Bangladesh ${ }^{14}$ aimed at exploring judicial attitudes towards the administration of criminal justice and, more specifically, the death penalty and judicial discretion in sentencing. There is a small but growing literature on interviewing 'elites', but little clarity on how to categorize potential interviewees as such. Elites in the criminal justice setting refer to '...individuals, who hold, or have held, a privileged position in society and, as such, ... are likely to have had more influence on political outcomes than general members of the public' (Richards 1996: 199). This can include ministers, judges, senior police, or prosecutors. While all criminal justice professionals being asked about the functioning or purpose of the criminal justice system could rightly be termed elites or 'professional elites' (McDowell 1998), some hold a significant amount of power or influence or can boast considerable knowledge about justice. Judges, even former judges, would fall into this category; they could perhaps be termed 'ultra elites' (Zuckerman 1972) given their position in a hierarchy of status within elite groups.

Elite interviews can offer 'an insight into the mindset of the actor/s who have played a role in shaping the society in which we live' (Richards 1996: 199-200). They do not reveal 'the truth'; accounts are inevitably subjective, reflecting an active process of creation of meanings (Portelli 2006). That said, recently retired judges may not worry about damage to their reputation as sitting judges might, and yet they have considerable experience to draw on, providing a window onto death penalty sentencing and also the wider criminal justice system in India and Bangladesh. Hence, these interviews were aimed at eliciting judges' understanding of motivations, concepts, laws, and sentencing rationale; their opinions about all of these; and insight into what has influenced those opinions.

It is important to consider the opinions of judges and their understanding of the criminal justice system because they hold considerable power to affect the lives of those before them, particularly in a jurisdiction that retains the death penalty. Judges should know the law better than other criminal justice personnel and apply it with independence and impartiality, without influence from the executive. However, evidence from a range of studies suggests that several extra-legal factors influence judicial decision-making; that judges are influenced by their own backgrounds as well as the backgrounds of those they are sentencing; that they sometimes rely on intuition; and that they are not always disinterested (Rachlinksi and Wistrich 2017).

\footnotetext{
${ }^{14}$ Interviews were conducted by the National Law University, Delhi and Bangladesh Institute of Law and International Affairs, with the support of the Death Penalty Project and the Universities of Oxford and Reading.
} 
Lawyers we spoke with prior to these studies told us that they could guess whether or not their clients would be sentenced to death simply by knowing which judge they would appear before. Such assertions of judge-centric sentencing need to be tested empirically. Furthermore, judges are better placed than any other actor in the criminal justice system to comment on pretrial as well as trial processes given that they hear evidence from both the prosecution and the defence on what has happened since an arrest. Their experiences therefore shine a light on the whole criminal process.

It is not easy to study judges, however. There is a long history of sitting judges refusing to cooperate with empirical research (for a review of judicial hostility to research, see Darbyshire 2011: 3-4). In some countries, such as the UK, it is hard; in others, it is impossible: following the publication of a study finding significant discrepancies across judges, France recently banned research on individual judicial behaviour and it is now a criminal offence to evaluate, analyse, or compare the sentencing behaviour of individual judges (Langford and Madsen 2019).

We were unlikely to persuade sitting judges to talk to us on such a sensitive topic. Furthermore, research suggests that sitting judges are defensive and poor at explaining their reasons for decisions (Genn 2008: 137). While much research is based on court judgments, we only used judgments to inform the development of the interview schedule and to prepare for individual interviews as alone they provided insufficient data. These challenges have persuaded some to study retired judges (Malleson 1999), though none that we are aware of focusing on death sentencing. Furthermore, while we are currently conducting research on elite opinions on the death penalty in the Caribbean, Zimbabwe, and Indonesia, we know of no other original elite studies on the death penalty. The research analysed in this article is therefore innovative.

\section{Challenges of Elite Interviews}

Like other elite professionals, judges are highly educated, self-assured individuals, whose work allows them to form opinions and make decisions that can have a significant impact on the lives of others. However, as Posner (2008: 7) puts it, 'judges are not intellectual giants, oracles or calculating machines, they are human workers, responding to the conditions around them'. In order to understand how these conditions shape their opinions and how those opinions might have persuaded them to apply the law in particular ways, we needed to persuade judges to agree to be interviewed and then be able to rely on their recall.

McDowell argues that elite interviewees are 'always powerful and usually knowledgeable, often on their guard, sometimes keen to demonstrate their relative power and knowledge and your relative power and ignorance' (1998: 2137). This was certainly the case in these interviews with judges, who were 'senior' to their interviewers not only in status but also in age. This could have presented challenges of access, but in both studies, the prestige of the universities associated with the research helped to persuade judges to cooperate, and while interviewers were relatively junior, the request for an interview, in both studies, came from a senior academic with an established reputation. However, the status and knowledge-base of elites can also pose challenges for the interview process. The interviewer must know as much as possible about the context, stance, and past behaviour of the subject before the interview as well as about the issues to be discussed so as not to waste judges' time or irritate them with apparently ignorant questions or comments (Hochschild 2009). Hence, interviewers were selected for their education and training in death penalty law and practice and each interview was carefully prepared for by reading relevant past judgments for each judge. 
There are risks associated with interviewing judges about cases they have presided over and judgments they have handed down some years after they have retired. Schacter et al. (2003: 228) warn of the dangers of memory, including transience relating to the accessibility of memory over time, and bias, where current knowledge and beliefs distort memories of the past. The judges we interviewed had impressive recall (Paterson found this too in his study of the UK Supreme Court; 2013: 7), and where there may have been difficulties, researchers were helped by having read their significant death penalty judgments before each interview and so could prompt memories and verify responses.

\section{Focus of the Interviews}

Following a small pilot study with three retired judges to test the interview schedule, where interviews were video-recorded to help researchers develop their interview skills, in-depth, semi-structured interviews were conducted by two interviewers at either the homes or offices of the judges. Interviews lasted between 90 and 120 minutes, and all but one judge consented to the use of a digital recorder. ${ }^{15}$ All interviews with Indian judges were conducted in English, while those with Bangladeshi judges were conducted in Bangla and translated to English after transcription. Interviews were conducted under rigorous ethical guidelines. ${ }^{16}$ Informed consent was obtained from all judges, who were told that they were free to refuse to answer any question without giving a reason and could withdraw from the interview at any time.

Interviews focused on the following: investigation and trial processes, sentencing norms and practices in capital cases, and judicial attitudes towards the death penalty. We were wary of probing for their personal views on the death penalty, given the emotive nature of the topic and their standing in society. However, we asked a series of questions which in most cases elicited these views without embarrassing or annoying judges, including (from the Bangladesh study; similar questions were asked of the Indian judges) the following questions asked at different stages of the interview:

'What are your thoughts on the death penalty in Bangladesh?'

'How do people in Bangladesh justify the retention of the death penalty?' 'What would

be your justification (if any) for the retention?'

'What are your thoughts on abolition of the death penalty?'

In other words, while we allowed them to talk in abstract, if they were reluctant to offer their own opinions, these questions, and others, could be-and typically were-interpreted as inviting their personal views. For example, one Indian judge was asked: 'what do you think is the main purpose of death penalty as a punishment?' and in a long reply, talking generally about retention rationales, he stated: 'I for one [think the] death penalty should be abolished'.

Another Indian judge, in answering a series of questions about sentencing in capital cases, commented, 'Therefore, if you ask me ultimately what is your view whether it should be abolished or remain in the statute, my view is that it should remain in the statute'. Further on in the interview, he clarified this position and explained the reasoning behind it: 'a rare case will appear where the cry of justice of the society really demand then the man should be executed'.

\footnotetext{
${ }_{15}$ In all regards, our interviews met recognised appropriate conditions for elites (Harvey 2011).

16 The Indian project was reviewed and approved by the University of Reading's Research Ethics Committee in June 2016. The Bangladesh project was reviewed and approved by the Dhaka University Research Ethics Committee in January 2017.
} 
In another interview, questions on sentencing elicited comments about inconsistencies and arbitrariness and prompted the judge to state: 'that's why I am of the view that we should abolish the death penalty'. In both of these cases, and others, their views on retention or abolition were volunteered before any questions on this matter.

\section{Sampling Judges}

\section{Indian Sample}

The Indian study identified - from the directory of all former Supreme Court judges - 86 former Supreme Court judges based in Delhi. All were invited for interview, but 26 declined or were unable to participate. Of the 60 former judges who were interviewed, seven were former Chief Justices of India, 24 had over 20 years of experience as appellate judges, and the remaining 33 judges had over 15 years of experience. The period in which they served as appellate judges spanned from 1975 to 2017, and between 47 of them, 208 death penalty cases were decided, and 92 death sentences confirmed.

\section{Bangladeshi Sample}

The Bangladeshi research team secured a list of retired District and Sessions Judges from the Retired Judges Welfare Association, with almost 180 contacts. Some were deceased and some were unable to participate in the study due to old age, ill health, or because they were based outside of Dhaka, reducing the list of potential interviewees to 40 Dhaka-based retired judges. As some of these refused to be interviewed, interviews were conducted with 30 former judges. Each began their career as a judge between 1977 and 1989, retired between 2006 and 2017, and served the judiciary for a period ranging from 25 to 34 years. All had decided death penalty cases, and the number of death sentences imposed ranged from about one hundred to none: five former judges had not imposed a single death sentence in their combined 141 years of judicial experience while 145 death sentences were passed by just three of the judges, indicating widespread disparity in death sentencing practice. ${ }^{17}$

\section{Integrity in the Criminal Process and Trial}

Integrity in the criminal justice system requires fair processes, transparency in decision making, opportunity for the defendant to have their say, and impartiality in decision-making. If our interviewees' experiences are typical, and we have no reason to believe that they are not, integrity is not a strong feature of criminal justice in India and Bangladesh.

We found considerable frustration among judges with the current, chaotic state of the criminal justice system in Bangladesh, and - to a lesser extent - in India. Judges expressed concerns about the use of torture; the fabrication of evidence; the lack of effective, state funded legal representation for capital defendants; and the consequent risk of wrongful convictions and wrongful acquittals within broken criminal justice systems characterised by impunity and corruption.

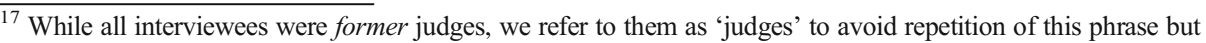
also because we focus on their practices when they were serving judges.
} 


\section{Investigation and Trial Process}

India and Bangladesh ratified the International Covenant on Civil and Political Rights (ICCPR) in 1979 and 2000, respectively. The legal consequences bear directly on the current use as well as the future of the death penalty. In addition to restricting the scope of the death penalty, this includes ensuring that all fair trial provisions and other provisions guaranteeing the protection of the rights of those facing the death penalty are respected in capital cases. Criminal sanctions can only be imposed against an individual who has been subject to due process of law which guarantees a presumption of innocence, a fair opportunity to answer the charges brought against them before a duly constituted court, and the assistance of effective defence counsel. Failure to ensure these factors in a capital case would render the sentence arbitrary and, consequently, in violation of article 6(1) of the ICCPR.

The human rights guarantees, under the ICCPR, are further reflected, developed, and interpreted through the United Nations Safeguards guaranteeing the rights of those facing the death penalty. ${ }^{18}$ The Safeguards require that fair trial standards be especially stringent in capital cases to account for the irrevocable nature of the penalty, a message that has been consistently reiterated. Most recently, the Human Rights Committee in its General Comment on the Right to Life listed an array of fair trial violations that may render an execution arbitrary, including:

the use of forced confessions; inability of the accused to question relevant witnesses; lack of effective representation during all stages of the criminal proceedings, ...; failure to respect the presumption of innocence ...; lack of an effective right of appeal; ...; excessive and unjustified delays in trial or the appeal process; and general lack of fairness of the criminal process, or lack of independent or impartiality of the trial or appeal court. ${ }^{19}$

In India, individuals are protected from the arbitrary and excessive powers of the state by the Constitution of India, the Criminal Procedure Code, the Indian Evidence Act, and various judgments of the Supreme Court of India. Bangladesh too has measures enshrined within its Constitution to protect defendants' due process rights, as well as legislation to address specific harms in the pre-trial process and Supreme Court judgments to clarify legislation. ${ }^{20}$

Despite these protections, not one of the 30 judges interviewed in Bangladesh was unequivocally positive in their views about the quality of the investigation and pre-trial process. Indeed, 19 were very critical about the fairness and quality of police investigations:

Investigation reports cannot be relied ... Sometimes [the police] even issue chargesheets against the innocent people. Our police officers are corrupt, and they have no accountability. (B 32/3 $3^{21}$ )

\footnotetext{
${ }^{18}$ The United Nations Economic and Social Council (ECOSOC) first adopted the Safeguards guaranteeing protection of the rights of those facing the death penalty in their Resolution No. 1984/50 of 25 May 1984; these Safeguards were further developed by the Council in Resolution 1989/64 of 24 May 1989 and 1996/15 of 23 July 1996.

${ }^{19}$ Human Rights Committee, General Comment, $C C P R / C / G C / 36,30$ October 2018, para. 41

${ }^{20}$ For example, Bangladesh vs. Bangladesh Legal Aid and Services Trust (BLAST) and others, 8 SCOB [2016] $\mathrm{AD} 1$.

${ }^{21}$ As all judges in both studies were promised anonymity and as each study report provides a complete list of all judges who were interviewed, we cannot provide an identification code for each quotation. Instead, quotes are labelled according to the jurisdiction (here, 'B' for Bangladesh), the number of years of judicial experience (here, 32 years) and the number of death sentences that judge has imposed during his career (here, 3). A dash (-) replaces missing information.
} 
Others asserted that the police regularly suppress inculpatory evidence in cases where powerful suspects are able to apply pressure and engage in corrupt practices. Conversely, the police were thought to withhold vital exculpatory evidence in cases where suspects are vulnerable and may have made false confessions under coercive conditions of police detention.

\section{Police Torture and the Reliability of Evidence in Court}

Torture is prohibited by international $\operatorname{law}^{22}$ and cannot be justified under any circumstance. It is also prohibited by national laws in both in Bangladesh and India. ${ }^{23}$ Notwithstanding, the majority of the judges were of the view that torture by police — both physical and mental — used to extract confessions is rampant. Most of our interviewees believed that confessional statements are typically the product of custodial torture, with voluntary confessions extremely rare:

Obviously, the police employ torture for extracting confessional statements in 100 out of 100 cases. (B 27/8)

When a person is sent to remand, he leaves the courtroom walking comfortably but when he is produced before the court after the remand, in many cases he barely can walk. (B 26/2)

Given widespread acknowledgment that confessions to police in India are sometimes extracted under coercive conditions or inducement, confessions are not ordinarily admitted as evidence in court. ${ }^{24}$ Almost two-thirds of the Indian judges believed that police officers circumvent this law, using torture to coerce suspects to sign blank sheets of paper or make statements that they can then use under the legislation for the purpose of the recovery of evidence. A quarter of the judges claimed to have had experiences of cases where evidence was planted. Some spoke of the considerable risk of wrongful convictions arising from such practices, particularly when uneducated and indigent suspects are unaware of their rights. Almost a quarter discussed the widespread use of 'false recovery witnesses': 'stock witnesses', frequently hired and paid to witness the apparent recovery of evidence. Some also spoke of the preparation of disclosure memos made after items have been recovered, rather than before, though dated as if completed in a procedurally correct manner.

Most (25) of the judges interviewed in Bangladesh had strong reasons to doubt the veracity of evidence presented by the prosecution (all but one acknowledged the prevalence of torture in police custody). As one interviewee put it:

Starting from the seizure list to the ballistic report, almost everything is tough to rely on without questioning the veracity. (B 31/0)

Indeed, only one Bangladeshi judge categorically stated that he never doubted the reliability of the evidence presented to him. More than half believed that evidence was sometimes planted by the prosecution.

\footnotetext{
${ }^{22}$ The Convention against Torture and Other Cruel, Inhuman or Degrading Treatment or Punishment was adopted by the General Assembly on 10 December 1984 and entered into force on 26 June 1987.

${ }^{23}$ The Torture and Custodial Death (Prevention) Act, 2013 in Bangladesh and sections 330, 331, 348 of the Indian Penal Code.

${ }^{24}$ Indian Evidence Act 1872, Sections 24, 25. Section 27 provides a limited exception where a statement is admissible insofar as it directly related to the discovery of physical evidence.
} 
Clearly, in Bangladesh, as in India, some suspects tortured by police do not find adequate protection in the criminal courts. ${ }^{25}$ But what of the lawyers who are meant to protect defendants from such abuses of due process of law?

\section{Legal Representation}

Given the obvious flaws in the pre-trial processes in Bangladesh and India, defendants need effective lawyers. The right to a fair trial under article 21 of the Constitution of India guarantees a right to legal representation and the Supreme Court, 40 years later, stipulated that the defence should be 'effective and meaningful'. ${ }^{26}$ As the vast majority of India's prison population are poor, belonging to marginalised and vulnerable sections of society (Law Commission of India 2015; National Law University, Delhi 2016), indigent persons being tried before a Court of Sessions are required to be provided with a defence lawyer at the expense of the State. ${ }^{27}$ Nonetheless, the Indian judges interviewed were largely in agreement that legal representation was unsatisfactory, disproportionately impacting the underprivileged. They pointed out several systemic deficiencies with the legal aid system with some asserting that lawyers sometimes failed to appear in the cases they undertook, or cases were attended only by their juniors, leaving defendants with inexperienced and ineffective counsel.

Laws in Bangladesh similarly guarantee the right of an accused to be defended by a privately appointed lawyer, ${ }^{28}$ and the state has a further obligation to appoint a defence lawyer for an unrepresented person charged with an offence punishable by the death penalty. ${ }^{29}$ Notwithstanding, half of the Bangladeshi judges interviewed were of the view that legal representation was of a poor standard, with a few persuaded that standards were deteriorating:

If you do not have money, then you can't get a good lawyer. In fact, especially in murder cases, you can't find lawyers who will work for underprivileged people. (B 27/0)

Just under a third considered that defence lawyers presented insufficient mitigating evidence:

Defence lawyers rarely plead mitigation. (B 28/6)

Defence lawyers generally do not present [mitigating] factors before the court; rather they prefer to hide these factors. (B 31/0)

Indeed, only one felt that representation was satisfactory.

Over two-thirds of the judges felt that prosecution lawyers were below standard, with almost all claiming that corruption is prevalent. It was suggested that prosecutors are unaccountable and that they often manipulate evidence, cause delays to proceedings, and are responsible for unwarranted convictions and acquittals:

Most of the prosecution lawyers in ... Bangladesh are [evil]. If you give them money, they will remain silent and if you do not ..., they will be using all their talent and knowledge. They can make and unmake any fact whatever. (B 29/10)

The prosecution often gets purchased by those who are accused and therefore, they act accordingly. These politically appointed public prosecutors are not accountable to anyone. (B 28/3)

\footnotetext{
${ }^{25}$ Shahdeen (2007:259) also found that police torture during remand went unchallenged.

${ }^{26}$ Kishore Chand v. State of Himachal Pradesh AIR (1990) SC 2140.

${ }^{27}$ Code of Criminal Procedure 1973, Section 304.

28 The Code of Criminal Procedure 1898, section 340.

29 The Legal Remembrancer's Manual, 1960, Chapter XII.
} 
In a system characterized by inadequate due process protections and poor legal representation, wrongful convictions can be expected, especially in capital cases where the stakes are high.

\section{Wrongful Convictions}

Most of the Indian judges acknowledged the existence of wrongful convictions, with only six being adamant that they had not encountered any such instances during their tenure. Furthermore, only seven who were aware of wrongful convictions were confident that the appellate process would correct such errors. In Bangladesh, 29 of the 30 judges accepted that wrongful convictions do or may occur. One was persuaded that they occur 'in many cases' (B 25/0), though about a third thought they were rare.

Judges in both countries attributed wrongful convictions to improper investigations (citing perjury, police corruption and fabrication of evidence); poor legal representation; political or media pressure; and 'any error committed by a judge' (B 31/3), though — not surprisingly — a few were adamant that judges were blameless:

Wrongful convictions occur because of a number of factors. ... Only the judges' inability to scrutinize the evidence and facts is not to blame. I am frustrated with the system. (B 28/10)

While others shared this frustration, and eight judges were more concerned about wrongful acquittals due to a lack of reliable evidence, some interviewees justified the lack of integrity in the criminal process by reference to utilitarianism.

\section{Utilitarian Accounts of Injustice: Corruption as a 'Necessary Evil'}

It was not surprising to us that judges would be cognisant of the prevalence of pre-trial torture and corruption, given that the limited research in both jurisdictions ${ }^{30}$ makes clear that these are endemic, particularly for the purpose of extracting confessions. However, we were interested in how judges made sense of unjust systems. Many interviewees were inherently opposed to torture, with some objecting on both principled and utilitarian grounds, seeing it as 'barbaric' as well as 'unreliable', as it is prone to coercing confessions from innocent people. However, unexpectedly, six of the 30 Bangladeshi judges justified torture, mainly on utilitarian grounds:

... police have to employ third degree methods for extracting confessional statements because there are some born criminals. They will not confess without being tortured. (B 23/1)

Of the 38 Indian judges who discussed torture, just under a third (12) saw it as a necessary evil because the police are inadequately resourced to investigate cases properly as they are:

either lazy, or don't have enough manpower, or do not know methods of scientific investigation. ( $\left./ 10^{31}\right)$

\footnotetext{
${ }^{30}$ For India, see: National Law University, Delhi 2016; Asian Centre for Human Rights 2011; People's Watch, 2008. For Bangladesh, see: Rafiqul and Solaiman 2003:26.

${ }^{31}$ Our information on judges' time in office and number of cases sentenced to death in the Indian study is incomplete. Therefore, we provide either numbers, where available, with the number of death sentences imposed always following a back slash (here, 10) and the years as a judge before (no information here).
} 
In Bangladesh, magistrates should not record a confessional statement unless they are persuaded that it has been made voluntarily, with forced confessions inadmissible in evidence. However, interviews suggested some tolerance within the courts for evidence produced following custodial torture, with one experienced judge explaining that:

many magistrates, despite having the knowledge of torture, certify confessional statements as voluntary. (B 27/-)

Some judges justified this position because, in their view, suspects rarely voluntarily confess their guilt:

We, the judges and magistrates, also understand that physical abuse is essentially required for extracting confessional statements. Given this reality, we try to be soft on the police and do not look much into the issues of forced confession... (B 27/26)

Indeed, one suggested that if it was clear that forced confessional statements were true, they would likely be regarded as admissible:

If it is seen that confession is not voluntary but true, judges do not discard confessional statements. (B 28/2) $)^{32}$

These utilitarian views were clearly at odds with the law and with the position that judges are meant to adopt, as principled arbiters of justice. If judges are prepared to overlook others' misconduct in the pursuit of securing convictions, are they any more principled in their own task of sentencing in these flawed cases?

\section{An Arbitrary Approach to Sentencing in Capital Cases}

As we make clear in our introduction, under the rarest of rare (Bachan Singh) doctrine, in India, in death sentencing, judges are meant to first identify and then balance aggravating with mitigating factors. Since 2003, the High Court Division of the Supreme Court of Bangladesh has, in several cases, endorsed the rarest of rare doctrine as formulated by the Indian Supreme Court, though the jurisprudence is not so well developed.

Many of the judges interviewed in India and Bangladesh had decided death penalty cases, some in the highest judicial forum, providing a unique opportunity to understand first hand sentencing practices. That these judges revealed considerable confusion about death penalty sentencing on multiple fronts is a cause for unease. The meaning of the rarest of rare, the identification of aggravating and mitigating factors, the balancing of those factors, and establishing that the alternative option of life imprisonment is unquestionably foreclosed all emerged as areas of confusion, ambiguity, and inconsistency.

\section{The Meaning of the Rarest of Rare}

Interviews confirmed that the rarest of rare doctrine was not sufficiently helpful in structuring discretion in sentencing death penalty cases and inadequate training further militated against

\footnotetext{
${ }^{32}$ This comment clearly contradicts the requirement in law that 'the confession should not only be voluntary but must also be true'. (The High Court Division of the Supreme Court of Bangladesh in the case of State vs. Md. Ali Kibria, 43 DLR (HCD) (1991) 512).
} 
principled and uniform sentencing. Indeed, eight judges were clear that the vagueness of the doctrine was the biggest factor in creating unfettered discretion:

It's totally unfettered discretion. Where to choose?... What should the yardstick be?... The disparity is so huge! ...there is no sound sentencing policy. (I -/100)

It can be safely said that the Bachan Singh threshold of rarest of rare cases has been most variedly and inconsistently applied [giving] rise to a state of uncertainty in capital sentencing law which clearly falls foul of constitutional due process and equality principle. (I -/-)

Even a former Chief Justice of India admitted that the formulation was unclear, and that he did not understand what it really meant, explaining that all murders are brutal and there was insufficient guidance on how to differentiate between them. In his view, there are two tests: one considers the brutality of the murder, and the other the shock to social and collective conscience, an interpretation which does not reflect the original formulation or the evolving jurisprudence.

Those Indian judges who explicitly articulated their understanding of the rarest of rare doctrine (who had decided 80 death penalty cases among them and confirmed 41 death sentences) expressed a considerable variety of meanings often at variance with the framework laid down in Bachan Singh. Some, erroneously, adopted an approach that understood rarest of rare as an issue of crime categories (for example, the rape and murder of a minor). ${ }^{33}$ Other judges felt that the requirements of the Bachan Singh doctrine would be satisfied under certain aggravating factors, such as the number of victims or weapons used, leaving no room for mitigation.

Until recently, Bangladesh retained mandatory death penalty laws for specific offences. However, in the case of BLAST and others vs. Bangladesh and others ${ }^{34}$ (popularly known as the 'Shukur Ali' case), the apex court of the country ruled that mandatory death penalty provisions are unconstitutional. Since then, judges have had to exercise discretion in determining whether to impose a death sentence in all capital cases. However, without proper guidance on sentencing discretion, jurisprudence similarly demonstrates little uniformity in Bangladesh. The Supreme Court does not consistently apply the rarest of rare doctrine, and the higher judiciary has taken markedly different positions across cases.

Most Bangladeshi judges were of the view that discretion is essential for ensuring justice, but just under a third felt that the death sentence was the default:

According to law, life imprisonment and death are not two options. The normal rule is death penalty. If the prosecution can prove the case beyond doubt, a judge has to go for death penalty. (B 33/7)

Indeed, one judge went as far as to deny the existence of discretion, observing that:

Judges have no discretion in awarding death sentence. If an offence is punishable with death and it is proved beyond any reasonable doubt, a judge is bound to give death penalty. (B 25/5)

\footnotetext{
33 This tendency to be 'crime-centric' in sentencing has been borne out by conversations we have had with practicing lawyers and judges in India outside of this study.

34 SCOB [2015] AD 1 .
} 
The other two-thirds did not consider death to be the rule in such cases and saw sentencing discretion as vital for just punishments, with 14 judges categorically asserting that they tried to follow the rarest of rare doctrine, though some thought that more guidance was needed:

It is important to have discretion. At the same time, ... in absence of a proper guideline, even the judges may take wrong decision. (B 25/0)

\section{Confusion About Aggravation, Mitigation and Reformation}

While the decision in Bachan Singh provides an indicative list of aggravating and mitigating factors, judges had widely different views on what constituted aggravation and mitigation and how they should be balanced.

Indian judges tended to give priority to aggravating factors and exclude certain mitigation features. In particular, they gave undue weight to the brutality and heinous nature of crimes but also to the vulnerability of the victim. In clear contradiction to Bachan Singh, six judges suggested wholescale rejection of mitigation as a requirement in death penalty sentencing. Others pronounced that mitigation is simply an excuse for the crime or was wholly irrelevant in particularly heinous offences. A few of the Bangladeshi judges also argued that mitigating factors should not be considered in certain crimes, including rape followed by murder or murder resulting from an acid attack:

Mitigating circumstances should not be considered if the offence is very cruel. (B 25/5)

Similarly, particularly brutal offences could dissuade Indian judges from giving adequate consideration to the possibility that the defendant could be reformed. Ten judges were of the view that the prospects for reform could be deduced from the seriousness of the crime. More ominously, 14 judges stated that the possibility of reformation should have no application to death penalty cases:

A man who is determined to kill innocent persons...how do you expect to reform him?... and reform him for what purpose and how ... and what will happen after he's reformed in the jail? Are we going to release him? (I -/13)

While the Bachan Singh judgment prohibits sentencing judges from considering public opinion, 11 judges - who had between them confirmed 41 death sentences - explicitly referred to the 'collective conscience' as a relevant aggravating factor:

[the collective conscience] is a relevant consideration so far as punishment is concerned, because punishment has to be proportionate... It can only be judged with respect to ... how the public feels about it, and what the public thinks about it. (I -/-)

Furthermore, two-thirds of the Bangladeshi judges felt that public opinion and media pressure had an impact on the sentences passed by some judges:

Public conscience and media pressure may often influence judges. Judges are after all human beings. (B 27/0)

Media pressure can influence a judge while sentencing an offender. Some cases receive huge media coverage and judges consider such cases differently (B 32/3) 


\section{Judge-Centric Sentencing}

It has been established elsewhere that death penalty sentencing in India is judge-centric, with similar cases resulting in very different outcomes (Law Commission of India 2015:10; Batra 2008). In the absence of clear sentencing guidelines and confusion about what should count as mitigating or aggravating features, over half of the Indian judges were of the view that discretion was guided significantly by the judges' backgrounds, particularly their class, sociocultural status, and religious beliefs:

... at the end of the day, every judge has his own concept of what is rarest of rare. (I 21/-

Some people like to give the death sentence, some people say no, I have no right to take somebody's life. That depends on ... a judge's background. (I 18/-)

One judge who had decided 90 cases in the appellate courts summed up concerns expressed by many others:

On the same considerations, different people react differently. And that is the strongest reason why I am against the death penalty. I find it horrible and terrifying, the subjective element in death penalty sentencing. If $\mathrm{X}$ is hearing my case, I will end up hanging from a rope, but if Y is hearing it instead, I'll live.... What Amnesty International has said in the Lethal Lottery report describes it very well, really. (I -/-)

Without adequate guidance, some Bangladeshi judges expressed views that suggested they were similarly capricious in their sentencing. When explicitly asked if they thought sentencing in death penalty cases was judge-centric, almost all replied in the affirmative, with just three arguing that it is judge-centric 'only to some extent'. None believed that sentencing is uniform in its application. They explained that inconsistencies arose from the personalities of the judges, the extent to which they were punitive or liberal, the demeanour of the defendant, and even the experience and knowledge of the judges:

Yes, death sentencing practice in Bangladesh varies from judge to judge. Some judges award capital punishment quite easily or frequently; they think it's a matter of credit to award death penalty. On the contrary, some judges remain very careful while awarding death penalty. This varies depending on the morality, honesty, knowledge of law and high ambition of the judges. (B 32/3)

What is absolutely clear from these interviews is that Bangladeshi and Indian judges are similarly confused, arbitrary, and judge-centric in their sentencing of capital cases; they fail to understand adequately the rarest of rare doctrine and the importance of mitigating factors; their decisions are influenced by their own personal backgrounds; and some seem to be unperturbed by such arbitrariness among those responsible for deciding who will live and who will die.

\section{Utilitarian Justifications for the Death Penalty}

Thus far, the empirical data has demonstrated unequivocally that these judges are fully aware of the considerable flaws in the investigation, trial, and sentencing of capital cases. The Marshall hypothesis would predict that they would be profoundly opposed to the death penalty. 
While we did not explicitly ask the Indian judges for their position on the death penalty, the views of 55 of the 60 judges emerged (see methods section above) and showed that 44 were retentionist, while 11 were abolitionists. The 11 abolitionists heard 61 death penalty cases between them in the Supreme Court and confirmed 19 death sentences, while the 44 retentionist judges confirmed 86 death sentences in 163 death sentence appeals. Hence, the abolitionists confirmed death sentences in just under a third of their cases, whereas retentionists confirmed death sentences in over a half their cases, perhaps suggesting that personal politics may have played a part in the judicial practices of these judges.

Nineteen of the 24 judges in Bangladesh who expressed their views were in favour of retention of the death penalty, while five were in favour of abolition. Though the samples were relatively small, particularly in Bangladesh where we draw on only 30 interviews (with twice as many in India), almost the same proportion were retentionist: $80 \%$ in India and $79 \%$ in Bangladesh, despite the rather different levels in the use of the death penalty in these two countries, as described in the introduction.

While 43 of the Indian judges had acknowledged the possibility of error while discussing the general state of India's criminal justice system, only a small proportion of these considered this to be relevant to their stance on the death penalty:

...there will be too many uncertainties in investigation and trial. You may have imposed death sentence on someone who is not really guilty! (I -/3)

Other judges felt that arbitrariness in the administration of the death penalty, and, in particular, judge-centric sentencing, were strong justifications for abolition. Some were of the view that the death penalty served no penological purpose, and others had principled objections concerning the sanctity of life or the potential for offenders to be reformed. We heard a range of justifications for abolition from Bangladeshi judges: namely, that no useful purpose is served by the death penalty; that it promotes enmity between those affected by serious crime; that it amounts to 'judicial murder'; and that it is inconsistent with the tenets of a civilised nation:

I don't support the death penalty... As a civilized nation, we cannot murder a murderer... We cannot be cruel simply because the offender is cruel. (B 26/3)

Of main concern to us here, however, is the preponderance of judges favouring retention, given their knowledge of their unjust systems.

Bangladeshi and Indian judges who expressed a preference for retention of the death penalty provided different rationales, but most were consequentialist. Only five expressed retributive justifications (four of them Indian judges):

Perhaps I do have this instinct of retribution; that...you have harmed someone in such a brutal, wrong way that perhaps this can be your only punishment. I won't give death sentence very easily, normally. But ... the instinct of retribution is not completely extinguished in my own psyche. (I -/1)

The purpose of death penalty is merely retributive - to pay evil back with evil. (B 28/3)

A few maintained that the death penalty should be retained due to the current socio-economic and cultural context within Bangladesh. While they could envisage abolition in the future, they argued that the time has yet to come and that the conditions in Bangladesh (in terms of economic development as well as the knowledge, awareness and attitudes of the people) are in sharp contrast with other countries that have abolished the death penalty: 
Our country is not a civilised one yet. I believe, it will take another fifty years for us to get properly developed. In the present contexts, the death penalty needs to be retained. (B 27/26)

I ... believe in human rights and therefore I do not support the death penalty. But I think, considering the situations prevalent in Bangladesh, the death penalty should be retained. (B 31/0)

A few Indian judges similarly felt that the 'Indian psyche' was not yet ready for abolition, with one estimating that it would take at least another 50 years before abolition would be contemplated by Indian society.

In a somewhat related point, two judges justified retention on the basis that abolition would run contrary to societal expectations. One felt that the purpose was to maintain social harmony and another to preserve people's trust in the judicial system:

In our country the people support the retention of the death penalty. They believe that the society loses its balance if the death penalty is not awarded for serious offences. (B 34/1)

These judges thought the death penalty could hold offenders to account in a disorganised or dysfunctional justice system of the type they had described earlier in the interviews. While this was not a clear consequentialist rationale for retention, it was an expression of faith in the most punitive punishment to uphold people's trust in the justice system, even when they were clear that the system was undependable.

However, the vast majority gave pure utilitarian reasons for retention:

The main purpose of awarding death penalty is to prevent people from committing heinous crimes. It works as an effective deterrent. (B 33/-)

I think the death penalty should be retained as a deterrent punishment so that no person in society has the audacity to kill any other person illegally. ... a death sentence reduces the tendency of killing. (B 32/3)

Some compared death sentences with life prison sentences:

The death sentence has a greater deterrent effect than life imprisonment because ... [it] creates a sensation among the people which prevents future crimes. (B 25/0)

Others were also worried that life sentenced prisoners may be released, by using their political connections; that the death penalty was necessary for the permanent incapacitation of the most dangerous offenders:

... it would be too dangerous to abolish ... there are many kinds of criminals, some of them are bloodthirsty and cannot be reformed. If death penalty is abolished, they will be a menace to the society. (I -/-)

Empirical evidence from the USA, Singapore, and Hong Kong suggesting that the death penalty does not produce a greater deterrent effect than can be achieved by a sentence of life imprisonment was thought to be unpersuasive (Cohen-Cole et al. 2009; Zimring et al. 2010). Many espoused intuitive 'beliefs' in deterrence, dismissing the need for statistics to prove a deterrent effect by stating that it was not 'a game of numbers' and that statistics from other countries could not be applied in their country:

India lives in rural areas. After a trial, if a person is convicted and given the death penalty, it creates a sensation in the entire village. People talk. That itself creates some 
kind of terror in the village and is a big factor in containing criminal tendencies of human beings. (I -/2)

\section{Contradictions in Judicial Support for Capital Punishment}

Research has established that support for the death penalty often rests on a belief that the criminal justice system can be administered without error. When members of the public with retentionist impulses are asked whether they would still favour the death penalty if it were proven to their satisfaction that an innocent person had been executed, support declines significantly (e.g. Sato 2018; Hood and Seemungal 2012; Cheong et al. 2018).

Both studies presented here revealed that judges were fully aware of the corruption, torture, fabricated evidence, and other abuses of due process in the criminal justice systems of Bangladesh and India. They knew that these conditions are likely to lead to wrongful convictions. Judges had a poor opinion of both defence and prosecution lawyers, recognising that they failed to protect defendants from corrupt practices in the pre-trial investigation and from failures by magistrates and judges to dismiss evidence collected by improper means.

Judges were similarly clear that the criminal justice systems in Bangladesh and India failed to guard against arbitrary sentencing in death penalty cases and that offenders convicted of serious crimes do not receive equal treatment under the law; that the death penalty is highly discriminatory and disproportionately affects the economically disadvantaged and those belonging to racial, ethnic, and religious minorities and is often used as a tool for silencing political opposition. They understood that imposing a death sentence is largely dependent on who the judge is and what his or her views on the death penalty are and that sentencing is judge-centric and something of a 'lethal lottery' (Batra 2008).

Marshall's hypothesised that when provided with rigorous evidence of its flaws, public opinion would turn against the death penalty. However, a paradox emerges from these studies: knowledge of an irretrievably defective system did not engender denunciation of the ultimate penalty. Despite personal knowledge of its flaws beyond that of members of the public, many judges have trust in the death penalty to deter crime and to realise other sentencing aims and feel retention benefits society.

Marshall's only explanation for those whose opinions do not change in the face of awareness of procedural and other flaws was that their support was based on vengeful retributive rationales that cannot be altered by such information. However, only a few of the judges offered retributive rationales; most maintained that the death penalty should be retained for its deterrent efficacy in reducing serious crimes, with a few relying on contextual arguments related to the socio-economic or cultural conditions.

The key reason for this paradox would appear to be a strongly utilitarian approach to justice at all stages of the criminal process. Not only did our judges express strongly utilitarian justifications for sentencing people to death, in terms of their erroneous belief in its deterrent effect, but some also articulated utilitarian justifications for misconduct in pre-trial processes, suggesting that it was necessary to break the rules to secure convictions when the system was dysfunctional and ineffective. They accepted misconduct as a necessary evil in overburdened and under-resourced systems. The very information that would persuade significant proportions of the general public that the death penalty should not be applied within justice systems that cannot be trusted to protect the rights of defendants was presented by some judges as a justification for retention. Only when such systems could be improved, at some time in the 
future, they argued, could the death penalty be abolished. Clearly, in the minds of these judges, utilitarianism trumped human rights for those exposed to corrupt and unreliable processes.

Acknowledgements Interviews were conducted by the National Law University of Delhi (NLUD) and Bangladesh Institute of Law and International Affairs (BILIA). Dr Mai Sato, of the University of Reading (now of Australian National University), assisted with data analysis and training of the researchers in India. The empirical data for the Indian research is presented in a report published by NLUD, Matters of Judgment. The data for the Bangladeshi study is published in a report by Bangladesh Institute of Law and International Affairs.

Compliance with ethical standards All procedures in these studies were in accordance with the ethical standards of British Society of Criminology. Informed consent was obtained from all individual participants included in the study. The Indian project was reviewed and approved by the University of Reading's Research Ethics Committee in June 2016. The Bangladesh project was reviewed and approved by the Dhaka University Research Ethics Committee in January 2017.

Conflict of interest The authors declare that they have no conflict of interest.

Open Access This article is distributed under the terms of the Creative Commons Attribution 4.0 International License (http://creativecommons.org/licenses/by/4.0/), which permits unrestricted use, distribution, and reproduction in any medium, provided you give appropriate credit to the original author(s) and the source, provide a link to the Creative Commons license, and indicate if changes were made.

\section{References}

Amnesty International. (2018). Death sentences and Executions 2017.

Amnesty International. (2019). Death sentences and executions 2018.

Asian Centre for Human Rights. (2011). Torture in India 2011. New Delhi.

Batra, B. (2008). Lethal lottery: the death penalty in India: a study of supreme court judgments in death penalty cases 1950-2006, Amnesty International.

Baumgartner, F. R., DeBoef, S. L., \& Boydstun, A. E. (2008). The decline of the death penalty and the discovery of innocence. Cambridge: Cambridge University Press.

Bohm, R. M. (2003). American death penalty opinion: past, present, and future. In J. R. Acker, R. M. Bohm, \& C. S. Lanier (Eds.), America's experiment with capital punishment (2nd ed., pp. 27-54). Durham: Carolina Academic Press.

Bohm, R. M., \& Vogel, R. E. (1994). A comparison of factors associated with uninformed and informed death penalty opinions. Journal of Criminal Justice, 22, 125-143.

Cheong, C. W., Ser, T. E., Lee, J., \& Mathi, B. (2018). Public opinion on the death penalty in Singapore: survey findings, National University of Singapore, Faculty of Law Working Paper, at https://law.nus.edu. sg/wps/pdfs/002_2018_Chan\%20Wing\%20Cheong.pdf. Accessed 1 Nov 2019.

Cochran, C. M., \& Cochran, J. K. (2011). The effects of information on change in death penalty support: raceand gender-specific extensions of the Marshall hypotheses. Journal of Ethnicity in Criminal Justice, 9(4), 291-313.

Cohen-Cole, E., Durlauf, S., Fagan, J., \& Nagin, D. (2009). Model uncertainty and the deterrent effect of capital punishment. American Law and Economics Review, 11(2), 335-369.

Darbyshire, P. (2011). Sitting in judgment: the working lives of judges. Oxford: Hart Publishing.

FIDH. (2010). Bangladesh: criminal justice through the prism of capital punishment and the fight against terrorism.

Genn, H. (2008). Judging civil justice. Cambridge: Cambridge University Press.

Harvey, W. S. (2011). Strategies for conducting elite interviews. Qualitative Research, 11(4), 431-441.

Hochschild, J. (2009) Conducting intensive and elite interviews, workshop on interdisciplinary standards for systematic qualitative research [internet] https://scholar.harvard.edu/jlhochschild/publications/conductingintensive-interviews-and-elite-interviews. Accessed 1 Nov 2019.

Hood, R. (2018). Is public opinion a justifiable reason not to abolish the death penalty? A comparative analysis of surveys in eight countries. Berkeley Journal of Criminal Law, 23, 218-242. 
Hood, R., \& Hoyle, C. (2017). Towards the global elimination of the death penalty: a cruel, inhuman and degrading punishment. In P. Carlin \& L. Franca (Eds.), Alternative criminologies, ch. 24. Abingdon: Routledge.

Hood, R., \& Seemungal, F. (2012). Public opinion on the mandatory death penalty in Trinidad. London: The Death Penalty Project.

Khondaker, M. I., Lambert, E. G., \& Jiang, S. (2011). Death penalty views in Bangladesh: an exploratory study of capital punishment views among Bangladeshi college students. International Journal of Comparative and Applied Criminal Justice, 35(2), 123-140.

Langford, M., \& Madsen, M. R. (2019). France criminalises research on judges, Verfassungsblog, at https://verfassungsblog.de/france-criminalises-research-on-judges/. Accessed 1 Nov 2019.

Law Commission of India. (2015). 262 nd report, The death penalty.

Lehrfreund, S. (2013). The impact and importance of international human rights standards: Asia in world perspective. In R. Hood \& S. Deva (Eds.), Confronting capital punishment in Asia: human rights, politics, and public opinion. Oxford: Oxford University Press.

Lehrfreund, S., \& Hood, R. (2016). The inevitability of arbitrariness: another aspect of victimisation in capital punishment laws in United Nations (ed.) Death penalty and the victims.

Malleson, K. (1999). The new judiciary: the effects of expansion and activism. Dartmouth: Aldershot.

McDowell, L. (1998). Elites in the city of London: some methodological considerations. Environment and Planning, 30, 2133-2146.

Middleton, J., Clift-Mathews, A., \& Fitzgerald, E. (2018). Sentencing in capital cases. London: The Death Penalty Project.

Mitchell, A. D. (2006). The effect of the Marshall hypothesis on attitudes toward the death penalty. Race, Gender and Class, 13(1), 221-247.

National Crime Records Bureau. (2017). Crime in India, 2016 at http://ncrb.gov.in/StatPublications/CII/CII2016 /pdfs/NEWPDFs/Crime\%20in\%20India\%20-\%202016\%20Complete\%20PDF\%20291117.pdf. Accessed 1 Nov 2019.

National Law University, Delhi. (2016). Death penalty India report, at https:/www.project39a.com/dpir. Accessed 1 Nov 2019.

Paterson, A. (2013). Final judgment: the last law lords and the supreme court. Oxford: Hart Publishing.

People's Watch (National Project on Preventing Torture in India). (2008). Torture and impunity in India, Madurai.

Portelli, A. (2006). What makes oral history different. In R. Perks \& A. Thomson (Eds.), The oral history reader (pp. 63-74). London: Routledge.

Posner, R. A. (2008). How judges think. Cambridge: Harvard University Press.

Project 39a. (2018). Death penalty in India: annual statistics report, at https://static1.squarespace.com/static/5 a 843a 9 a 9 f0 7 f5ccd61685f3/t/5c5020c003ce6447fb54cb66/1548755150348/Project+39 A+Annual+Statistics.pdf. Accessed 1 Nov 2019.

Rachlinksi, J. J., \& Wistrich, A. J. (2017). Judging the judiciary by the numbers: empirical research on judges. Annual Review of Law and Social Science, 13, 203-229.

Rafiqul, I. M., \& Solaiman, S. M. (2003). Torture under police remand in Bangladesh: a culture of impunity for gross violations of human rights. Asia-Pacific Journal on Human Rights and the Law, 4(2), 1-27.

Rahman, M. M. (2017). Criminal sentencing in Bangladesh: from colonial legacies to modernity. Leiden: Brill Nijhoff.

Richards, D. (1996). Elite interviewing: approaches and pitfalls. Politics, 16(3).

Sato, M. (2014). The death penalty in Japan: will the public tolerate abolition? Berlin: Springer.

Sato, M. (2018). 12 Years without an execution: is Zimbabwe ready for abolition? London: The Death Penalty Project.

Schacter, D. L., Chiao, J. Y., \& Mitchell, J. P. (2003). The seven sins of memory: implications for self. Annals of the New York Academy of Sciences, 1001, 226-239.

Shahdeen, M. (2007). Arrest and remand: judicial interpretation and police practice. Bangladesh Journal of Law, $259-292$.

Zimring, F. E., Fagan, F., \& Johnson, D. (2010). Executions, deterrence and homicide: a tale of two cities. Journal of Empirical Legal Studies, 7(1), 1-29.

Zuckerman, H. A. (1972). Interviewing an ultra-elite. The Public Opinion Quarterly, 36, 159-175.

Publisher's Note Springer Nature remains neutral with regard to jurisdictional claims in published maps and institutional affiliations. 